\title{
Household Choice of Purifying Drinking Water in Cameroon
}

\author{
Armand Luc Fotuè Totouom (Corresponding author) \\ Faculty of economics sciences and management, University of Yaoundé II \\ P.O. Box 1365, Yaoundé, Cameroon \\ Tel: 237-75-76-71-25Ｅ-mail: tofolucar@yahoo.fr
}

Fondo Sikod

Faculty of economics sciences and management, University of Yaoundé II P.O. Box 1365, Yaoundé, Cameroon

Tel: 237-77-50-08-69Ｅ-mail: fsikod2002@yahoo.com

\author{
Ibrahim Abba \\ Ministry of Employment and Vocational Training \\ P.O. Box 16273, Yaoundé, Cameroon \\ Tel: 237-99-16-53-97_E-mail: ibab20032002@yahoo.fr
}

Received: April 16, 2012 Accepted: May 3, 2012

doi:10.5296/emsd.v1i2.1642ＵRL: http://dx.doi.org/10.5296/emsd.v1i2.1642

\begin{abstract}
This study contributes to the still short literature on demand for drinking water quality in Africa by modeling Cameroonian households' choice of purifying drinking water. Specifically, the study seeks to: analyze households' access to water and various measures undertaken to improve water quality; identify the factors driving households' decision to purify drinking water. Our analysis uses data from the second Multiple Indicators Cluster Survey carried out in 2006 by the National Institute of Statistics. In order to control for possible simultaneity of the choice of drinking water source and the decision to purify water or not before drinking it, a bivariate probit model is used for discrete analysis. Most previous studies have neglected to consider this issue in their analysis. Our findings suggest that
\end{abstract}


households' educational level has a positive and statistically significant impact on households' decision to purify water before drinking it. Results also reveal that wealth quintile, health status and number of children less than five years strongly affect households' decision. In particular, the magnitude of the wealth quintile impact on households' decision is larger than those of the other variables. Implications for drinking water policies are discussed.

Keywords: Water purification, bivariate probit model, Cameroon

\section{Introduction}

Safe and affordable supply of potable water is a basic need for human life. In recent years, access to safe and reliable water supplies has received increased governments attention from around the world. Today, the Millennium Development Goal aims at reducing the proportion of people without sustainable access to safe drinking water and basic sanitation to half by 2015.

Household water supply has become an important public policy issue because safe water is mainly an essential component of primary health care. In fact, access to improved water sources and sanitation is related to health and survival to human capital (Mangyo, 2008; Tang et al., 2008; Mishra \& Newhouse, 2009). In Developing countries (DC), contaminated drinking water is a major health hazard (Jalan et al., 2009) and water-related diseases are a significant contributor to the global burden of illness. The common diseases here are waterborne: 1.8 millions of people ( $90 \%$ are less than 5 years old) die every year due to waterborne diseases like cholera, mainly in DC (OMS, 2005). Furthermore, 21\% of infant mortality in DC is caused by diarrhoeal diseases (UN-Water/WWAP, 2006). Moreover, 88\% of the cases of diarrhoeal disease are attributed to unsafe water supply, inadequate sanitation and hygiene.

Though essential for human life, more than one billion on the earth lack access to safe drinking water. The problem is more crucial in DC and generally does not lie with the scarcity of water, but with the difficulties to finance water supply and treatment operations (Diakité et al., 2009). In Cameroon, access to an improved water supply remains a major concern: less than $30 \%$ and $40 \%$ of the population have access to potable water in urban and rural area respectively (Missions Economiques, 2005).

According to the World Health Organization (WHO), an improvement in the supply of water may reduce by $25 \%$ death due to diarrhoea. Unfortunately, one of the major problems with public utilities such as drinking water in DC is unreliable and low quality supply. Households cannot be secured from water-borne and water-related diseases when the quality of the drinking water is questionable. They usually undertake various averting strategies such as boiling, filtering or buying bottled water to improve water quality and reduce health risks of drinking contaminated water. Improvements in drinking water quality through household water treatment can lead to a reduction of diarrhoeal episodes by 39\% (OMS, 2005).

The Analysis of the households' averting behaviour is important in designing policy for water services. Through policy implications, it may help to reduce the water-borne diseases by influencing the behaviours. Such analysis is based on the household production function 
theory of consumer behaviour. The household produces consumption goods using various inputs, some of which are subject to degradation. Households may respond to increased degradation of these inputs in various ways that are generally referred to as averting or defensive behaviours so as to avoid the adverse impacts of water contaminants. This includes filtering water or boiling water before drinking it.

Although an extensive empirical literature exists on households' choice of purifying water before drinking, few such studies exist for African countries. The nature and magnitude of such factors that determine households' choice are not yet clearly understood or reported in household water literature in Africa. The aim of the present article is to help remedy this by investigating Cameroonian households' choice of purifying drinking water. Specifically, the study seeks to:

- $\quad$ analyze households' access to water and various measures undertaken to improve water quality;

- $\quad$ identify the factors driving households’ decision to purify drinking water

Our analysis uses data from the second Multiple Indicators Cluster Survey (MICS2) conducted in 2006 by the National Institute of Statistics. The bivariate probit model is used for discrete analysis. The rest of the paper is organized as follows: Section 2 provides a brief overview of empirically related work. Section 3 presents the main methodological issues. Empirical results are described in Section 4, while policy implications and conclusion are found in Section 5.

\section{Literature Review}

Since water quality cannot be measured through market system, various non market valuation methods have been developed to assess the benefit of water quality. Two basic approaches are used to estimate household's Willingness to Pay (WTP) for improvement in quality of water: the direct and the indirect approach. The direct approach is based on stated preference. The most direct method frequently used for estimation of WTP is the contingent valuation method (CVM).

The Indirect approach is based on the observation of the averting strategies people undertake to improve the quality of their drinking water. The amount of additional money spent to reduce apparent health risks is considered to be equal to the WTP for improvement in water quality. A number of earlier studies using the averting behaviour approach to analyse households' demand for water purification have been conducted in the early 1990s (Abdalla et al., 1992; Whitehead et al., 1998, etc.). In recent years, such studies have received increased economists attention.

Larson and Gnedenko (1999) examine household demand for water purification in Moscow. Survey results show that: over $88 \%$ of the sample boils water regularly due to concerns about water quality; 23 percent filter water regularly; over 30\% settle water regularly; and about $13 \%$ buy bottled water regularly. A logistic regression framework is used to model the probability that a given respondent uses a specific avoidance measure (boil, settle, filter, and buy bottled water). Estimation results suggest that income affect the choice of purchasing 
bottled water, using filter and boiling. They also suggest that there is less filtering of water in the North and East locations as compared to Rublevo and West and the opinion on quality of water only affect the choice of settling water.

Abrahms et al., (2000) use a multinomial model to investigate averting behaviour of Geogia (United Stated) residents. Their study shows that perceived risk from tap water, concern about water quality, race and age are the most important determinants of bottled water demand. Information about problems related to tap water, perceived risk from tap water, and income are the most important determinants of water filter choice.

McConnell and Rosado (2000) use the data from Brazil and find that the demand for home purification is positively affected by factors such as income, education and presence of young children in the household. Income and education are also some of the variables that positively affect the demand for home purification in the study of Dasgupta (2004). Among the factors affecting the choice of a specific purification method, McConnell and Rosado (2000) found that the more and alternative costs, the less likely it will be choose.

Bukenya (2006) study is based on data from a sample of 487 surveyed households in Uganda. A simultaneous probit regression model is estimated to identify the determinants of the choice of a specific purification method (boiling, buying bottled water or a combination). His findings indicate a strong relationship between income, educational level, presence of children in the household, location, and opinion on water quality on the type of avoidance measures undertaken to improve water. Results also show that boiling reduces the likelihood of household buying bottled water but demand for bottled water does not reduce the use of boiling water strategy.

Based on a household survey conducted in Abbottabad (Pakistan), Haq et al. (2007) found that there are statistically significant effects of education on the water purification behaviour of the households. They also found that, higher income quartile is highly significant in all coping strategies. The variables "tap" and "fetching" have a significant impact on the water purification behaviour contrary to the variable "well". The study suggests that there is a strong effect of the quality of water on all water purification behaviour of households.

Nauges and Van Den Berg (2009) show that a higher perceived risk increases the probability that households boil or filter water before drinking it. In their study, they estimate a single probit model, since the Likelihood-Ratio test of the bivariate probit model previously chosen shows that decisions related to water source and purification adoption are independent.

Jalan et al. (2009) use a household survey from urban India to estimate the effects of awareness proxies (education of adult household members, their exposure to mass media like newspapers, television or radio, and their occupations) on home water purification. They find that these measures of awareness have statistically significant effects on home purification and, therefore, on WTP for water quality. The magnitudes of these effects are by no means small and are comparable to the wealth effects. Ahmed and Sattar (2007) and Ahmad et al. (2010) also find that measures of awareness such as different level of schooling of decision-makers and household heads and their exposure to mass media have statistically 
significant effects on home purification methods for drinking water

The results of the logistic regression analysis used by Anderson et al. (2010) shows that the less clean the water and the more distant the water source, the more likely the rural African households in South Africa is to perceive water pollution as a problem. Households with less clean water, more educated household members, and that perceive water pollution as a problem are more likely to treat their water; education of household members and monthly household expenditures do not matter. Boiling and chemicals are the most common treatment methods (93.6\%). Households with less clean water, with more educated members, with higher overall expenditures and with a more distant water source are more likely to chemically treat their water than to use another treatment option.

Based on a survey of 10,000 households in OCDE, the study of Johnstonne and Serret (2012) reveal that negative perceptions of tap water quality affect the decision to purchase bottled water and home purification, with much greater effect on bottled water consumption. The same is true of household income. Household size, the presence of children in the household and length of residence affects the decision to invest in purification, but not bottled water consumption. The study also suggests that concern about solid waste has a negative impact on bottled water consumption, and car ownership has a positive impact.

\section{Methodology}

In this paper, we describe a simple approach for estimating the significance of the factors believed to influence households' choice of purifying water before drinking in Cameroon. The decision to adopt improved drinking water source and the decision to treat water are model simultaneously through a bivariate probit model. We first present the source of the data used in the study. Second, we specify the econometric model used for discrete analysis.

\subsection{Data Source}

In this study, we use micro data to analyze households' choice for water purification. For this purpose, we rely on data from the second Multiple Indicators Cluster Survey (MICS2) conducted in 2006 by the National Institute of Statistics. The MICS2 is a household survey program developed by United Nations Children's Fund (UNICEF) to assist countries in filling data gaps for monitoring the situation of women and children. It is intended to provide data to support analysis, planning, assessment, and advocacy for children in a range of areas including education, health, nutrition, children's rights, and protection. The MICS2 produces data measuring progress toward the Millennium Development Goals, World Fit for Children, and other major relevant international commitments. Among the cross-section of 9856 households selected for interviewed (5 449 in rural area and 5307 in urban area), 9848 were clearly identified. From the sub sample of identified households, 9667 were successfully interviewed.

The questionnaire yielded several information on many variables such as respondent characteristics (age, relationship to household head, etc.), household characteristics (size, educational level of household head, etc.), and household health. The questionnaire also furnished information related to water uses and consumption. This information are: source of 
water, distance to water source, time taken to reach the water source, person in charge of collecting water, and water purification strategies adopted.

\subsection{Econometric Model}

The most used econometric models for choice analysis are the probit and the multinomial logit (MNL) models. Even if these models are widely used in the literature to analyze households' demand for improved water, it is worth noting that this approach has a shortcoming. In fact, previous studies using these models for coping strategies analysis implicitly assume that the choice of water source and the adoption of water purification are not simultaneously determined. Yet, there are some reasons to think that the choice of the drinking water source is likely not to be independent of the choice to purify or not drinking water. Therefore, we have to control for possible simultaneity of the two choices.

Our approach to estimation is similar to that used in Nauges and Van Den Berg (2009). However, contrary to these authors who estimate separate bivariate probit models for each water source considered, we estimate here a single bivariate probit model, since we only consider whether or not the source of water used is an improved one. Suppose $T_{i}=1$ the probability that household $i$ choose to treat water before drinking and $T_{i}=0$ the same probability if the water is not treated. Also suppose that $S_{i}=1$ is the probability that household $i$ choose an improved water source for drinking purpose and $S_{i}=0$ the same probability if an unimproved source is chosen. In accord with the WHO definition, we consider in our study the following sources as improved sources: private tap, connected neighbour, collective tap/standpipe, borehole, protected wells, rain water and protected spring. In this study, we also consider bottled water as improved water supply. In fact, the WHO classifies bottled water as unimproved water supply because of the limited amount of that supply (the amount of bottled water consumed daily by individuals is generally below 20 liters / day) and not due to quality. The others sources that surveyed households rely on are considered here as unimproved sources.

The observed variables $S_{i}$ and $T_{i}$ are related to the unobserved latent variables $S_{i}{ }_{i}$ and $T^{*}{ }_{i}$ respectively. In order to take into account the fact that the choice of the drinking water source is likely not to be independent of the adoption of a purification method, we model simultaneously the two choices as follow:

$$
\left\{\begin{array}{l}
\left\{\begin{array}{l}
S_{i}=1 \text { if } S^{*}{ }_{i}=\alpha X_{i}+\varepsilon_{1}>0 \\
S_{i}=0 \text { if } S *_{i}=\alpha X_{i}+\varepsilon_{1} \leq 0
\end{array}\right. \\
\left\{\begin{array}{l}
T_{i}=1 \text { if } T^{*}{ }_{i}=\beta X_{i}+\varepsilon_{2}>0 \\
T_{i}=0 \text { if } T *_{i}=\beta X_{i}+\varepsilon_{2} \leq 0
\end{array}\right.
\end{array}\right.
$$

Equations (1) and (2) are assume to be linear in parameters. $\alpha$ and $\beta$ are the vectors of parameters to be estimated. $\varepsilon_{1}$ and $\varepsilon_{2}$ are disturbance terms and they are assumed to be normally distributed: 


$$
E\left[\varepsilon_{1}\right]=E\left[\varepsilon_{2}\right]=0 \text { and } V\left[\varepsilon_{1}\right]=V\left[\varepsilon_{2}\right]=1
$$

Moreover, $\varepsilon_{1}$ and $\varepsilon_{2}$ are assumed not to be independent: $\operatorname{cov}\left[\varepsilon_{1} \varepsilon_{2}\right]=\rho$

$\rho$ is the constant representing the coefficient of correlation between $\varepsilon_{1}$ and $\varepsilon_{2}$. The test of $\rho=0$ will be used to test the existence of an interdependent relation between the two households' decisions (choice of water source and choice of purification). If the null hypothesis that $\rho$ equals zero is rejected, there is indication that the households' decisions are not independent, and the above model is estimated in a bivariate probit model. If the null hypothesis cannot be rejected, equations (1) and (2) are estimated separately.

$\mathrm{X}$ is the vector of the exogenous variables presented in table 1.

Table 1. Explanatory variables

\begin{tabular}{|c|c|}
\hline Variables & Description \\
\hline Sex & Gender of the household head ( 1 if the male, 0 otherwise) \\
\hline $\begin{array}{l}\text { Education } \\
\text { primary educ }\end{array}$ & $\begin{array}{l}\text { Educational level of the household head ( } 1 \text { if he has at least the } \\
\text { al level, } 0 \text { otherwise) }\end{array}$ \\
\hline Location & Household living area (1 if living in urban area, 0 otherwise) \\
\hline Children & number of children less than five years in the family (continuous) \\
\hline $\begin{array}{l}\text { Wealth } \\
\text { variable, whi } \\
\text { of wealthy at }\end{array}$ & $\begin{array}{l}\text { Quintile of the Household wealth index. It is a categorical } \\
\text { been classified as five dummies, each representing a certain level } \\
\text { ent }\end{array}$ \\
\hline $\begin{array}{l}\text { Healthstatus } \\
\text { one case of il }\end{array}$ & $\begin{array}{l}\text { Health status of household ( } 1 \text { if the household reports at least } \\
\text { luring the } 30 \text { last days preceding the survey, } 0 \text { otherwise) }\end{array}$ \\
\hline
\end{tabular}

The above explanatory variables have been selected based on the literature and the availability of the related data in MICS2 dataset.

\section{Empirical results}

\subsection{Households'Access to Water and Various Measures Undertaken to Improve Water Quality}

Cameroon has adopted two different systems of supplying water to the population: a national network to supply water in urban areas and a system of fixed rural potable water point to supply water in rural areas. The country has more than 100 drinking water urban stations and more than 3000 stations and rural water points (Missions Economiques 2005). Urban stations are managed by "La Camerounaise des Eaux", while stations and rural water points are managed by users (village communities) under the supervision of the authorities. In spite the fact that the national coverage rate for improved water service has gradually improved, we can observe that the Cameroonian supply of water system has partially failed since millions of people still do not get drinking water from an improved water source. The observations from MICS2 data reveal that several households rely on unimproved sources. Among the 
9667 surveyed households, only 1153 (12\%) used piped network as their main drinking water source. Among the households without a house connection, 1884 meet their drinking water demand from public taps/standpipe, 750 from their connected neighbors, 1194 from unprotected spring, 669 from protected spring, 1013 from unprotected well, 675 from protected wells, 1356 from borehole, 830 from surface water (streams, river, etc.), and 81 from vendors (tanker and carter). Consumption of rain and bottled waters is still marginal among the surveyed households (17 and 32 respectively).

As in DC, households may collect water from more than one water source: a main source (the most reliable and safest sources) to collect drinking and cooking water and a second or more sources (the least reliable and safest) to collect water for other usages (washing, watering, bathing, etc.). In fact, households usually use either one source or a combination of several sources. Among the surveyed households, 2636 (27.26\%) rely on several water supply sources. Alternative sources of water used by surveyed households are reported in the appendix.

Coping sources are costly to reach since time and energy spent for fetching water could be used more efficiently for agriculture or schooling for instance. Average time taken to fetch water is 26 minutes. There is however inequality among users. For $29 \%$ of the surveyed households, the average distance to the collection site is less than 15 minutes while it is equal or up to 1 hour for $10 \%$ of the households.

A large majority of households reports that water is mostly collected by adults (71\%). Women are more involve in water collection task (46\%) than men (26\%). Although children are not the principal collector, the MICS2 shows that there is equality among young boys (14\%) and young girls (15\%).

Concerning the measures undertaken by Cameroonian households to cope with unreliable water quality so as to minimize health hazards from contaminated water, a total of 1002 surveyed households (10.4\%) declare that they purify water before drinking it. This indicate that there is more evidence to believe that for a given household of the overall sample, the household is likely satisfy with the quality of its drinking water. Of the total of households who treat their water, 168 boil water, 395 filter water, 366 used chemicals (chlorine or bleach), 136 decant water and 15 used other methods. 72 surveyed households combined several purification methods.

Among the 3131 households (32.39\% of the whole sample) relying on unimproved sources, 2 847 households do not purify water before drinking while the 284 remaining households purify it. Among the 6536 households (67.61\% of the whole sample) relying on improved sources, 5818 do not purify water before drinking while the 718 remaining households purify it.

\subsection{Descriptive Statistics of the Explanatory Variables of the Econometric Model}

Table 2 gives the descriptive statistics of the explanatory variables. 


\section{Macrothink

Table 2. Descriptive statistics of the explanatory variables

\begin{tabular}{lcccc}
\hline Variables & Mean & $\begin{array}{c}\text { Standard } \\
\text { deviation }\end{array}$ & Min & Max \\
\hline Location & 0.461 & 0.498 & 0 & 1 \\
Children & 0.672 & 0.951 & 0 & 10 \\
Sex & 0.750 & 0.433 & 0 & 1 \\
Education & 0.735 & 0.441 & 0 & 1 \\
Healthstatus & 0.391 & 0.488 & 0 & 1 \\
Bottom Wealth quintile & 0.176 & 0.381 & 0 & 1 \\
Second wealth quintile & 0.206 & 0.404 & 0 & 1 \\
Third wealth quintile & 0.201 & 0.401 & 0 & 1 \\
Fourth wealth quintile & 0.206 & 0.404 & 0 & 1 \\
Top wealth quintile & 0.211 & 0.408 & 0 & 1 \\
\hline
\end{tabular}

On average, $46 \%$ of households live in urban areas. This result is not too far from the one of the Third General Population and Housing Census (GPHC) of 2005 in Cameroon. The third GPHC states that the rate of urbanization in the country was $48.8 \%$ in 2005 . The average number of children less than five years per household is 0.672 . The number of children per household varies from zero to ten. Among the surveyed households, close to $40 \%$ experience a case of illness among the members during the 30 last days preceding the survey. About $75 \%$ of the respondents are male-headed households. Concerning the educational level of household heads, data reveals that majority of the household heads (73.5\%) have at least the primary educational level; Meaning that about 26.5\% of household heads are illiterates. $17.6 \%$ of the households belong to the bottom wealth quintile, $20.6 \%$ to the second wealth quintile, $20.01 \%$ to the third wealth quintile, $20.6 \%$ to the fourth wealth quintile, and $21.12 \%$ to the top wealth quintile.

\subsection{Determinants of the Demand for Water Purification}

In estimating the model, we removed all the households that had missing values in any of explanatory or dependent variables. Estimation results of the bivariate probit model are given in Table 3. The model is first test for overall model specification using a chi-squared test, which is a test of the joint significance of all the explanatory variables. The test show that at least one explanatory variable has explanatory power on the joint outcome variable (the chi-squared statistic is significant at $1 \%$ ). The Likelihood-ratio test of $\rho=0$ indicates that the null hypothesis of independence between source and purification decisions can be rejected at the $1 \%$. In this regard, bivariate probit estimation is more appropriate than the single-equation probit model. The estimated coefficients are difficult to interpret directly. For this, we have calculated marginal effects of each variable. They measure the impacts of one unit change in explanatory variables on the estimated probability of adopting a purification method or adopting an improved source. These marginal effects are estimated at sample means. 
Table 3. Bivariate probit regression results

\begin{tabular}{|c|c|c|c|c|}
\hline \multirow{2}{*}{ Variables } & \multicolumn{2}{|c|}{ source } & \multicolumn{2}{|c|}{ purification } \\
\hline & coefficients & $\begin{array}{l}\text { Marginal } \\
\text { effects }\end{array}$ & coefficients & Marginal effects \\
\hline Location & $\begin{array}{c}0.455 \\
(0.040)^{* * *}\end{array}$ & $\begin{array}{c}0.141 \\
(0.012)^{* * *}\end{array}$ & $\begin{array}{c}0.042 \\
(0.049)\end{array}$ & $\begin{array}{c}0.007 \\
(0.008)\end{array}$ \\
\hline Children & $\begin{array}{c}0.011 \\
(0.016)\end{array}$ & $\begin{array}{c}0.004 \\
(0.005)\end{array}$ & $\begin{array}{c}0.033 \\
(0.019) *\end{array}$ & $\begin{array}{c}0.006 \\
(0.003)^{*}\end{array}$ \\
\hline Sex & $\begin{array}{c}-0.155 \\
(0.037)^{* * *}\end{array}$ & $\begin{array}{c}-0.047 \\
(0.011)^{* * *}\end{array}$ & $\begin{array}{c}0.026 \\
(0.043)\end{array}$ & $\begin{array}{c}0.004 \\
(0.007)\end{array}$ \\
\hline education & $\begin{array}{c}0.065 \\
(0.036)^{*}\end{array}$ & $\begin{array}{c}0.021 \\
(0.012)^{*}\end{array}$ & $\begin{array}{c}0.085 \\
(0.050) *\end{array}$ & $\begin{array}{c}0.014 \\
(0.008)^{*}\end{array}$ \\
\hline Healthstatus & $\begin{array}{c}0.044 \\
(0.032)\end{array}$ & $\begin{array}{c}0.014 \\
(0.010)\end{array}$ & $\begin{array}{c}0.143 \\
(0.036)^{* * *}\end{array}$ & $\begin{array}{c}0.025 \\
(0.006)^{* * *}\end{array}$ \\
\hline $\begin{array}{l}\text { Second wealth } \\
\text { quintile }\end{array}$ & $\begin{array}{c}0.271 \\
(0.044)^{* * *}\end{array}$ & $\begin{array}{c}0.080 \\
(0.12)^{* * *}\end{array}$ & $\begin{array}{c}-0.043 \\
(0.068)\end{array}$ & $\begin{array}{l}-0.007 \\
(0.011)\end{array}$ \\
\hline Third wealth quintile & $\begin{array}{c}0.663 \\
(0.047)^{* * *}\end{array}$ & $\begin{array}{c}0.178 \\
(0.011)^{* * *}\end{array}$ & $\begin{array}{c}0.143 \\
(0.067)^{* *}\end{array}$ & $\begin{array}{c}0.025 \\
(0.013)^{* *}\end{array}$ \\
\hline Fourth wealth quintile & $\begin{array}{c}1.135 \\
(0.058)^{* * *}\end{array}$ & $\begin{array}{c}0.300 \\
(0.009)^{* * *}\end{array}$ & $\begin{array}{c}0.186 \\
(0.075)^{* *}\end{array}$ & $\begin{array}{c}0.034 \\
(0.014)^{* *}\end{array}$ \\
\hline Top wealth quintile & $\begin{array}{c}2.108 \\
(0.083)^{* * *}\end{array}$ & $\begin{array}{c}0.393 \\
(0.008) * * *\end{array}$ & $\begin{array}{c}0.646 \\
(0.077)^{* * *}\end{array}$ & $\begin{array}{c}0.137 \\
(0.020)^{* * *}\end{array}$ \\
\hline Constant & $\begin{array}{c}-0.385 \\
(0.045)^{* * *}\end{array}$ & & $\begin{array}{c}-1.688 \\
(0.064)^{* * *}\end{array}$ & \\
\hline 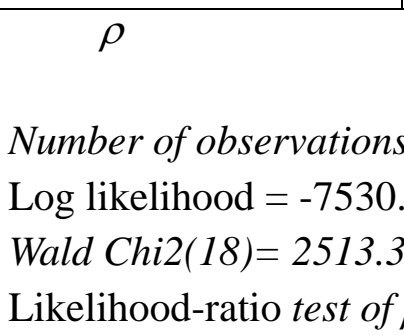 & $\begin{array}{l}-0.171 \\
(0.027)^{* * *} \\
9618 \\
094 \\
6, \text { Prob > chi } \\
\rho=0: \text { chi2(1) }\end{array}$ & $\begin{array}{l}0.000 \\
\text { 38.619, Prc }\end{array}$ & chi2 $=0.000$ & \\
\hline
\end{tabular}

The study measures the effect of households' educational level on the demand for improved water quality. Our findings show that households who are educated are more likely to treat water before drinking, as compared to households who are not educated (marginal effect is 0.014). This result is not surprising, since more educated households are probably more aware about adverse health effects from ingestion of poor water quality. Several other studies put in evidence the impact of education on the decision to purify water (McConnell and Rosado, 2000; Dasgupta, 2004; Nauges and Van Den Berg, 2009, etc.). The study also suggests that education increases the probability of adopting an improved water source. The 
probability of adopting an improved water source increases by 0.021 point for households who are educated as compared to households who are not educated. The significant effect of education on households' choice of drinking water source is in conformity with previous studies (Madanat and Humplick, 1993; Abebaw et al., 2010, etc.).

Place of residence is a strong determinant of households' choice to use an improved source. Living in urban area increases the probability of adopting an improved source by 0.141 point. For purifying water, the parameter for location is not statistically significant.

An important variable in the decision of households to purify water is the presence of children. The number of children less than five years increases the probability of purifying drinking water by 0.006 point. This finding is not surprising since it is obvious that children are more vulnerable to health effects from contaminated water than are adults. Thus, households are more sensitive to water quality issues in presence of children in the family. The impact of children's presence on household behaviour is also confirmed by Bukenya (2006) and Nauges and Van Den Berg (2009). The number of children also has a positive but not significant impact on the choice of the water source.

As expected, health status is a significant determinant of households' demand for purification (marginal effect is 0.025). This means that if a household experiences illness among the members in the past, then it is more likely to purify drinking water. In fact, households who experience illness are more risk-averse than healthy households and hence want to minimize water-borne illnesses by purifying drinking water to improve its quality. However, the variable is not a significant determinant of the decision to rely on improved water source.

Most of the existing studies suggest that female household heads are more likely to adopt a water purification strategy as compared to male-headed households. For instance, Ahmed and Sattar (2007) show in their study that the gender of decision-makers regarding water purification is statistically significant suggesting that female decision-makers are more likely to adopt some water purification device than male decision-makers. In contrast, our findings suggest that in Cameroon, male-headed households are more likely to purify water as compared to female-headed households (marginal effect is not significant). The results also suggest that male-headed households are less likely to use improved sources as compared to female-headed households.

In this model, we also explore the effect of households' welfare on households' decisions. The findings show that the wealth quintiles may have a significant impact on households' decisions. They significantly increase the probability of purifying water and the probability of collecting water from improved sources. All four categories representing second, third, fourth and top wealth quintile have a significant effect on households' decisions (with the exception of the second wealth quintile in the equation of the demand for purification). The interpretation seems to be that purifying water and collecting water from improved sources may involve significant cost so that the income constraint is a binding factor in the households' choices. Looking at the marginal effects at the different wealth quintile, it may be observed that the magnitude of the marginal effects is increasing as the wealth quintile is increased. This means that the effect of household wealth on the probability of adopting 
improved source and purification method is larger (in magnitude) for richer households.

\section{Conclusion and Policy Implications}

The analysis of the households demand for improved water quality is important in designing policy for water services. It may help to reduce the water borne diseases by influencing the behaviours through policy implications. This study investigates the averting behaviour of Cameroonian households. While modeling households' decision to purify water before drinking, a particular attention was accorded to the possible simultaneity of the choice of the drinking water source and the decision to purify or not water before drinking it, in order to get reliable results. Little attention has been given to this issue in most previous studies, although this issue may bias coefficients estimated. The bivariate probit model permits a test of correlation between the choice of the water source and the adoption of a purification method. We find that the correlation between the choice of the water source and the adoption of a purification method is positive and strongly significant. This result suggests that the use of a bivariate probit model in order to model both choices is justified.

The study measures the effect of education on the decision to adopt at least one purification method. Our findings suggest that households' educational level has a positive and statistically significant impact on households' decision to purify drinking water and to use improved sources. Therefore, authorities should popularize education in the country. This may be done by making primary education compulsory and ensuring the effective enforcement of the measures of free primary education adopted a decade ago. Such policies should increase people demand for safe water via the increasing of their awareness of the health risks of drinking contaminated water. The popularization of education should be a priority since we found that households mostly rely on unsafe water (of the 9667 surveyed households, only 6536 households rely on improved sources while only 1002 households treat water before dinking).

Our study suggests that households' experience of past health shock influences their purification behaviour. Results also confirm the fact that wealth quintile, health status and number of children less than five years may strongly affect households' decisions. Households belonging to the highest four wealth quintiles are more likely to adopt an improved source and a purification method, as compared to households belonging to the bottom wealth quintile. Our findings show that the magnitude of the wealth impact on households' decisions is larger than those of the other variables, showing the impact of wealth as a key factor in the households' choices. This implies that in order to increase population consumption of safer water, policymakers should mainly orientate their actions towards the reduction of poverty inside the population.

\section{References}

Abdalla, C. W., Roach, B. A., \& Epp., D. J. (1992). Valuing Environmental Quality Changes Using Averting Expenditures: An Application to Ground-water Contamination. Land Economics, 68, 163-69. http://dx.doi.org/10.2307/3146771

Abebaw, D., Tadesse, F., \& Mogues, T. (2010). Access to Improved Water Source and 
Satisfaction with Services Evidence from Rural Ethiopia. International Food Policy Research Institute Discussion Paper 01044. Available on: http://www.ifpri.org/sites/default/files/publications/ifpridp01044.pdf. (December 20, 2011).

Abrahams, N. A., Bryan, J. H., \& Jeffery, L. J. (2000). Joint Production and Averting Expenditure Measures of Willingness to Pay: Do Water Expenditures Really Measure Avoidance Costs?. American Journal of Agricultural Economics, 82, 427-37. http://dx.doi.org/10.1111/0002-9092.00036

Ahmad, I. Haq, M., \& Sat;,tar, A. (2010), Factors Determining Public Demand for Safe Drinking Water (A Case Study of District Peshawar), Pakistan Institute of Development Economics Working Papers 2010: 58. Available on: http://www.eaber.org/sites/default/files/documents/PIDE_Ahmad_2010.pdf (December 20, 2011)

Ahmed, E., \& Sttar, A. (2007). Awareness and the demand of safe drinking water practices. Pakistan Institute of Development Economics, Working Papers 2007:21. Available on: http://pide.org.pk/pdf/Working\%20Paper/Working\%20Paper-21.pdf (March 15, 2012).

Anderson, B. A., Romani, J. H., Wentzel, M., \& Phillips, H. E. (2002). Awareness of Water Pollution as a Problem and the Decision to Treat Drinking Water among Rural African Households with Unclean Drinking Water: South Africa 2005. Population Sudies Center. Research Report, Report 10-701. Available on: http://paa2011.princeton.edu/download.aspx?submissionId=110779 (March 2, 2012)

Bukenya, J. (2006). Household Perceptions of the Quality of drinking Water in Uganda. Selected Paper prepared for presentation at the Southern Agricultural Economics Association's Annual Meetings Orlando, Florida, February 5-8, 2006. Available on: http://ageconsearch.umn.edu/bitstream/35355/1/sp06bu01.pdf (July 25, 2011)

Dasgupta, P. (2004). Valuing health damages from water pollution in urban Delhi, India: a health production function approach. Environment and Development Economics, 9, 83-106. http://dx.doi.org/10.1017/S1355770X03001098

Diakité, D., Semenov, A., \& Alban, T. (2009). A proposal for social pricing of water supply in Cote d'Ivoire. Journal of Development Economics, 88(2), 258-268. http://dx.doi.org/10.1016/j.jdeveco.2008.03.003

Greene, W. H. (1996). Marginal Effects in the Bivariate Probit Model. Working Paper, Department of Economics, Stern School of Business. New York University, No. 96-11.

Haq, M., Mustafa, U., \& Ahmad, I. (2007). Household's Willingness to Pay for Safe Drinking Water: A Case Study of Abbottabad District. The Pakistan Development Review, 46, 1137-1153. Available on: http://mpra.ub.unimuenchen.de/15208/1/PDR_published_paper_WTP_for_safe_water1.pdf (December 17, 2011)

Human Development Report. (2006). Beyond scarcity: power, poverty and the global water 
crisis. United Nations Development Programme, New York. Available on: http://hdr.undp.org/en/reports/global/hdr2006 (June 12, 2011)

Jalan, J., Somanathan, E., \& Chaudhuri, S. (2009). Awareness and the demand for environmental quality: survey evidence on drinking water in urban India. Environment and Development Economics, 14(6), 665-692. http://dx.doi.org/10.1017/S1355770X08005020.

Johnstone, N., \& Serret, Y. (2012). Determinants of bottled and purified water consumption: results based on an OECD survey. Water Policy, 14(4), 668-679. http://dx.doi.org/10.2166/wp.2011.048

Larson, B. A., \& Gnedenko, E. D. (1999). .Avoiding health risks from drinking water in Moscow: An empirical analysis. Environment and Development Economics, 4, 565-581. http://dx.doi.org/10.1017/S1355770X99000339

Madanat, S., \& Humplick, F. (1993). A model of household choice of water supply systems in developing countries. Water Resources Research, 29, 1353-58. http://dx.doi.org/10.1029/93WR00126

Mangyo, E. (2008). The effect of water accessibility on child health in China. Journal of Health Economics, 27, 1343-1356. http://dx.doi.org/10.1016/j.jhealeco.2008.04.004

McConnell, K. E., \& Rosado, M. A. (2000). Valuing Discrete Improvements in Drinking Water Quality through Revealed Preferences. Water Resources Research, 36(6), 1575-82. http://dx.doi.org/10.1029/2000WR900043

Mishra, P., \& Newhouse, D. (2009). Does health aid matter? Journal of Health Economics, 28, 855-872. http://dx.doi.org/10.1016/j.jhealeco.2009.05.004

Missions Economiques. (2005). Le secteur de l'eau et de l'assainissement au Cameroun, Fiche de synthèse, Ambassade de France au Cameroun.

Nauges, C., \& Van Den Berg. (2009). Perception of health risk and averting behavior: An analysis of household water consumption in Southwest Sri Lanka. Toulouse School of Economics, Working paper series 09-139. Available on: http://www.tse-fr.eu/images/doc/wp/dev/wp_dev_139_2009.pdf (October 23, 2011)

OMS. (2005). Célébration de la Décennie Internationale d'Action "L'Eau source » de vie 2005-2015, Guide de sensibilisation. Available on: http://www.who.int/water_sanitation_health/2005advoguidefr.pdf (January 12, 2012)

Sharma, N. P., Damhaug, T., Gilgan-Hunt, E. et al. (1996). African water resources: challenges and opportunity for sustainable development. World Bank Technical paper 331. The World Bank, Washington, DC. Available on: http://library.wur.nl/isric/index2.html?url=http://library.wur.nl/WebQuery/isric/15103 (February 12, 2012)

Tang, K. K., Chin, J. T. C., \& Rao, D. S. P. (2008). Avoidable mortality risks and measurement of wellbeing and inequality. Journal of Health Economics, 27, 624-641. 


\section{Macrothink \\ Environmental Management and Sustainable Development \\ ISSN 2164-7682 \\ 2012, Vol. 1, No. 2}

http://dx.doi.org/10.1016/j.jhealeco.2007.08.003 PMid:18191488

UN-Water / WWAP. (2006). « L'eau : une responsabilité partagée », Résumé du $2^{\text {ème }}$ rapport mondial des Nations Unies sur la mise en valeur des ressources en eau. 52P. Available on: http://unesdoc.unesco.org/images/0014/001444/144409f.pdf (February 12, 2012).

Whitehead, J. C., Hoban, T. J., \& Van Houtven, G. (1998). Willingness to Pay and Drinking Water Quality: An Examination of the Averting Behavior Approach. Paper prepared for presentation at the 68th annual conference of the Southern Economic Association in Baltimore, MD, November 1998.

Appendix. Alternative sources of water used by survey households

\begin{tabular}{lccc}
\hline Sources & $\begin{array}{c}\text { Number of } \\
\text { households }\end{array}$ & percent & Valid percent \\
\hline Private tap & 1116 & 11.3 & 11.6 \\
Connected neighbor & 407 & 4.1 & 4.2 \\
Collective tap/standpipe & 1129 & 11.5 & 11.7 \\
borehole & 896 & 9.1 & 9.3 \\
Protected wells & 1628 & 16.5 & 16.8 \\
unprotected wells & 1598 & 16.2 & 16.5 \\
Unprotected spring & 1097 & 11.1 & 11.3 \\
Protected spring & 430 & 4.4 & 4.4 \\
Rain water & 112 & 1.1 & 1.2 \\
Vendors & 54 & 0.6 & 0.6 \\
Surface water & 1181 & 12 & 12.2 \\
Other & 14 & 0.1 & 0.1 \\
Misssing & 5 & 0.1 & 0.1 \\
Total & 9667 & 98.1 & 100 \\
Missing system & 189 & 1.9 & \\
Total & 9856 & 100 & \\
\hline
\end{tabular}

\section{Copyright Disclaimer}

Copyright reserved by the author(s).

This article is an open-access article distributed under the terms and conditions of the Creative Commons Attribution license (http://creativecommons.org/licenses/by/3.0/). 